\title{
Late Turonian-early Coniacian belemnites from western and central Europe
}

\author{
WALTER KEGEL CHRISTENSEN
}

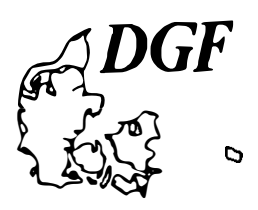

\begin{abstract}
Christensen, W. K.: Late Turonian-early Coniacian belemnites from westem and central Europe. Bull. geol. Soc. Denmark, vol. 31, pp. 63-79, Copenhagen, November 15th, 1982. https://doi.org/10.37570/bgsd-1982-31-06

A little known fauna of late Turonian-early Coniacian belemnites from the Central European palaeobiogeographic Subprovince is revised and the following species are recognised: Actinocamax strehlensis (Fritsch \& Schlōnbach), A. bohemicus Stolley, A. paderbornensis Schlüter, and A. esseniensis n. sp. The taxonomic value of various characters within Late Cretaceous belemnites belonging to the family Belemnitellidae Pavlov is discussed, and it is concluded that the shape of the guard is a more significant taxonomic character than the presence of granules. The species from the subprovince are compared to coeval species from the Central Russian Subprovince and the North American Province. The palaeobiogeography and evolutionary trends of early Late Cretaceous belemnites are discussed.
\end{abstract}

Walter Kegel Christensen, Geological Museum, Øster Voldgade 5-7, DK-1350 Copenhagen, Denmark. August 15th, 1982. This paper is a contribution to IGCP-Project No. 58, Mid-Cretaceous Events.

\section{Introduction}

Belemnites are virtually unknown in the late Turonian-early Coniacian in the Central European Subprovince of the North European Province (Christensen 1976). Altogether, less than a dozen specimens have been described or mentioned in the literature during the last hundred years. The specimens have been referred to four taxa: Actinocamax strehlensis (Fritsch \& Schlönbach), $A$. bohemicus Stolley, $A$. paderbornensis Schlüter, and $A$. plenus var. strehlensis. In contrast, belemnites are not uncommon in this period in the Central Russian Subprovince and include the following taxa: A. intermedius Arkhangelsky, A. medwedicicus (Naidin), A. matesovae (Naidin), " $A$." surensis Naidin, $A$. coronatus (Makhlin), and $A$. planus (Makhlin). Moreover, Naidin (1964) also reported various subspecies of $A$. verus Miller of Turonian age from the Subprovince. Turonian belemnites are also recorded from the North American Province and were referred to $A$. manitobensis (Whiteaves) by Jeletzky $(1950,1961)$. The main objective of the present paper is to redescribe the inadequately described or figured belemnites from the Central European Subprovince.

\section{Historical review}

Actinocamax strehlensis was established by Fritsch \& Schlönbach (1872) on the basis of four complete specimens and some fragments from Bohemia. Three specimens came from the Teplitzer Schichten at Strehlen near Dresden, and the fourth, granulated, specimen, which Stolley (1916) later referred to a new species of $A c$ tinocamax (see below), came from the Teplitzer Schichten at Kostic near Lauen. Fritsch \& Schlönbach distinguished $A$. strehlensis from $B e$ lemnites lanceolatus Sowerby, notably by its possession of a shallow pseudoalveolus, and they indicated that $A$. strehlensis occurs later than $B$. lanceolatus. It should be added that most cephalopod workers in the latter part of the eighteenth century considered $B$. lanceolatus Sowerby to be synonymous with $A$. plenus (Blainville) (see discussion in Christensen 1974). The two specimens figured as $B$. lanceolatus by Fritsch \& Schlönbach (1872, Pl. 11: 6-7) should be referred to $A$. plenus.

The legitimacy of $A$. strehlensis was questioned by Geinitz (1872-1875) who considered $A$. strehlensis to be synonymous with $A$. plenus. Nevertheless, he figured two specimens from the 
Pläner Limestone at Strehlen as Belemnitella plena var. strehlensis $(=A$. plenus var.strehlensis) (Geinitz 1872-1875, Pl. 31: 13-14). The two specimens came from a higher stratigrafic level than $A$. plenus. Schlüter $(1874,1876,1894)$ considered $A$. strehlensis to be a distinct species, but he made an unjustified emendation and referred to the species as $A$. strehlenensis. Grossouvre (1901-1903), Stolley (1916) and later workers considered $A$. strehlensis to be a legitimate species.

The two specimens figured as $B$. plena var. strehlensis by Geinitz (see above) were referred to A. strehlensis by Schlüter (1894), Jeletzky (1950), and Birkelund (1956). Jeletzky (1961), on the other hand, considered the two specimens described by Geinitz and $A$. strehlensis to be specifically distinct and tentatively assigned the two specimens of Geinitz to his new variety $A$. manitobensis var. spicularis.

Schlüter (1894), on the basis of a single fragment of the anterior part of the guard from supposedly Turonian deposits of the Münster Basin, created a new species $A$. paderbormensis, characterised by its large size, and said to carry granules.

Stolley (1916) referred the granulated specimen figured as $B$. strehlensis by Fritsch \& Schlönbach $(1872$, P. 16: 17) (see above) to a new species, $A$. bohemicus.

Naidin (1964) discussed at length the relationships of $A$. bohemicus, $A$. paderbornensis and $A$. plenus var. strehlensis. $\mathrm{He}$ was of the opinion that the single specimen of $A$. bohemicus and the two specimens of $A$. plenus var. strehlensis described by Geinitz (1872-1875) either should be referred to a distinct species, viz. $A$. bohemicus, or be considered a subspecies of $A$. strehlensis.

Barrois (1876) recorded an undeterminable belemnite fragment with affinity to $A$. strehlensis from the Turonian of Norfolk (Peake \& Hancock 1970), and Frič (= Fritsch) (1883, fig. 49) figured a fragment of a granulated belemnite from the Iser Schichten in Bohemia as Belemnites sp. The Iser Schichten is placed in the Middle Turonian, Zone of $I$. lamarcki, by Prescher (1981).

of the material mentioned above only the holotypes of $A$. bohemicus and $A$. paderbornensis and the two specimens of $A$. plenus var. strehlensis are preserved. The remaining material appears to be lost. Recently, three specimens of Ac- tinocamax of late Turonian-early Coniacian age have been found in Western Europe, and they are included in the present study.

\section{Stratigraphy}

The level of the Turonian-Coniacian boundary has been the subject of much discussion during the last ten years (Ernst \& Schulz 1974; Ernst, Schmid \& Klischies 1979; Hancock \& Kennedy 1981; Kennedy \& Hancock 1978; Kauffman 1978a, 1978b; Kauffman, Cobban \& Eicher 1978; Naidin 1981; Rawson et al. 1978; Seibertz 1979a, 1979b; and Tröger 1981a, 1981b). This is partly due to the fact that the basal Coniacian in the type area does not contain fossils of correlative value (Rawson et al. 1978), and that a modern exhaustive description of the boundary in the type area does not exist (van Hinte 1979). According to Rawson et al. (1978: 25) the base of the Coniacian must coincide with the base of the Senonian, and the standard formation usually taken as the base of the Senonian is the Craie de Villedieu of Touraine. The lowest member of this stratigraphical unit has yielded ammonites such as Barroisiceras haberfellneri, Peroniceras tricarinatum, Paratexanites zeilleri, Gauthiericeras margae, and Tissotia ewaldi. Following de Grossouvre (1901-1903) the Coniacian is subdivided into two ammonite zones: Barroisiceras haberfellneri below and Paratexanites emscheris above. This concept of the boundary has commonly been used in France, England, USA, and Russia. In northern Germany, Seitz $(1956,1959)$ put the base of the Coniacian at the first appearance of Inoceramus koeneni, because ammonites are very rare in this area. This concept was followed until recently in East Germany and Poland.

Correlation of the French and German strata at this critical level is rendered difficult on account of a lack of modern work on the French inoceramids, and because of the rarity of Coniacian ammonites in Germany. However, Seibertz (1979b) has recently recorded $B$. haberfellneri together with $I$. schloenbachi from the I. deformis Zone in the Münster Basin. Therefore, it is now known that the Upper Turonian sensu germanico is correlative with the Lower Coniacian sensu gallico.

Today, most Cretaceous stratigraphers seem to 


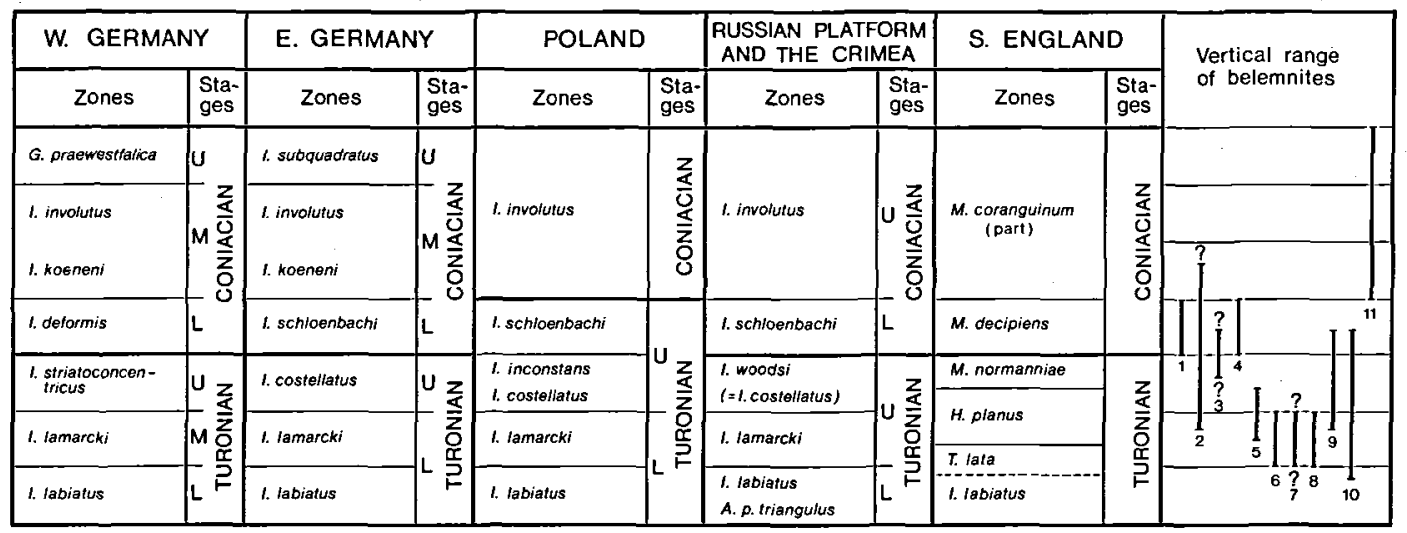

Fig. 1. Stratigraphical correlation diagram of the Turonian and Coniacian. It is based on Ernst, Schmid, Klischies (1979) and Seibertz (1979b) for W. Germany. Tröger (1981a, 1981b) for E. Germany, Sokolowski (1976) for Poland, Naidin (1981) for the Russian Platform and the Crimea, and Kennedy \& Hancock (1978) for southern England. According to Gale \& Woodroof (1981) the English $M$. normanniae Zone should be placed in the Coniacian on ammonite evidence. The vertical range of the revised belemnites and some other belemnites discussed in the text are shown. $1: A$. strehlensis. $2: A$. bohemicus. $3: A$. paderbornensis. $4: A$. esseniensis. $5: A$. aff. strehlensis recorded by Barrois (1876). 6: Belemnites sp. recorded by Fric (1883). 7: A. manitobensis. 8: $A$. coronatus. 9: $A$. intermedius. 10: A. medwedicicus. 11: Gonioteuthis westfalica mujnakensis. I. = Inoceramus. G. = Gonioteuthis. A.p. triangulus = Actinocamax plenus triangulus. $M .=$ Micraster. $H .=$ Holaster. $T .=$ Terebratulina.

agree upon the French concept of the boundary and, accordingly, the $I$. schloenbachi Zone or equivalent zones should be placed in the Lower Coniacian (Fig. 1). According to Tröger (1981a, 1981b) I. schloenbachi is a valid species and not a subspecies of $I$. deformis as suggested by Seitz (1956, 1959).

\section{Taxonomy}

The species concept of belemnites

The modern species concept in palaeontology is based on populations, rather than a few specimens (the so-called typological species concept). Species are studied by analysing large, homogeneous, populations from restricted stratigraphical intervals by means of various biometric methods. This concept has only recently been applied to Late Cretaceous belemnites (Kongiel 1962; Ernst 1964; Christensen 1971, 1973, 1974, 1975a, 1975b; Christensen et al. 1975; and Schulz 1979), and biometric studies have shown that many belemnite species and subspecies established by earlier workers are nothing but morphological variants. Unfortunately, it is not possible to use this procedure in the present study because (1) only very few specimens have been found, (2) these few specimens have been as- signed to several species, and (3) the exact age relations of the specimens are uncertain. Moreover, several belemnite species of more or less the same age have been erected in North America and the Russian Platform, and most of these taxa were also based on very few specimens. Thus, this study somehow represents a step back to the typological species concept, in which the species is interpreted with respect to its type and type-series if such exists. The present study, however, is supported by a general knowledge of the variability within other belemnite taxa.

\section{Taxonomic value of various characters}

The following characters generally are considered to be of taxonomic value in describing Late Cretaceous belemnites belonging to the Belemnitellidae: (1) size of guard, (2) shape of guard, (3) structure of the anterior part of the guard, (4) surface markings, (5) internal characters, and (6) ontogeny.

According to Jeletzky (1950) all Cenomanian and most Turonian and Coniacian species of the genus Actinocamax are extremely variable in nearly all their morphological characters, such as form of guard, ventral furrow, and structure of anterior end of the guard. Jeletzky (1961: 507), 
in his paper on Actinocamax from the Upper Cretaceous of Kansas, once more expressed the idea regarding the wide variation of morphological characters and proposed a diagnosis for $A$. manitobensis that is so comprehensive that many species of Actinocamax could be classified as $A$. manitobensis. On the other hand, Jeletzky (1950) stressed the great taxonomic significance of granulation within the genus Actinocamax, and he established a new species of Actinocamax, $A$. sternbergi, on the basis of only one granulated specimen (Jeletzky 1961).

The present author does not share the views of Jeletzky with regard to the wide morphological variation of early Late Cretaceous Actinocamax and the great taxonomic value of granulation. With regard to morphological variation the few biometric analysis which have been made on large, homogeneous, populations from restricted stratigraphic intervals of early Late Cretaceous age show no extreme variation. Thus, the author (1974) has analysed biometrically a large sample of $A$. plenus from the Upper Cenomanian Plenus Marls, and this study did not show an extreme variation with respect to the form of the guard or the structure of the anterior end of the guard. It was, however, demonstrated that the growth is allometric in this species. Juvenile specimens are slender, subcylindrical to slightly lanceolate in ventral view and subcylindrical in lateral view, while adult specimens are more stout, lanceolate to strongly lanceolate in ventral view and subcylindrical to slightly lanceolate in lateral view. Moreover, the analysis showed that most specimens have a low cone-shaped alveolar fracture, while a few specimens (about $7 \%$ of the sample) have a shallow pseudoalveolus, but the sample exhibits all intermediate forms. The same range of variation of the structure of the anterior part of the guard is also seen in Gonioteuthis westfalica from the Late Coniacian/Early Santonian (Ernst 1964; Christensen 1973, 1975a, 1976).

With regard to granulation, it was already demonstrated by Birkelund (1956), on the basis of Belemnellocamax grossouvrei ornatus (Moberg) from Sweden, that granulation can be present within a species which otherwise does not possess this character. Moreover, Naidin (1964:163) has described a granulated specimen of $B$. mammillatus which otherwise does not have this character. In addition, I have seen a granulated specimen of $B$. ex gr. grossouvrei in Prof. D.P. Naidin's collection in Moscow. The specimen came from early Campanian deposits in West Kazakhstan and was found together with Belemnitella praecursor Stolley. In the genus Gonioteuthis, the oldest member ( $G$. westfalica praewestfalica Ernst \& Schulz) does not possess granulation (Ernst \& Schulz 1974). The succeeding taxon, G. w. westfalica (Schlüter), shows a wide variation with respect to that character; some specimens are not granulated at all, some specimens carry scattered granules on the dorsal and/or ventral side of the guard, and sometimes the granules appear to be arranged in longitudinal rows. The same pattern is valid also for $G$. westfalicagranulata (Stolley). In stratigraphically younger species, however (in ascending order $G$. granulata (Blainville), G. granulataquadrata (Stolley), G. quadrata (Blainville), and G. quadrata gracilis (Stolley), the granulation becomes a very prominent character.

Plate 1. All figures are of natural size unless otherwise indicated. Specimens are coated with ammonium chloride.

Fig. 1. Actinocamax strehlensis (Fritsch \& Schlönbach, 1872). Lectotype. A: Ventral view. B: View of anterior end of guard. Reproduced from Fritsch \& Schlönbach, 1872, Pl. 16: 10.

Fig. 2. Actinocamax strehlensis (Fritsch \& Schlönbach, 1872). A: Lateral view. B: View of anterior end of guard. C: Ventral view of anterior end of guard, $\times 1.3$ approx. Reproduced from Fritsch \& Schlönbach, 1872, Pl. 16: 11.

Fig. 3. Actinocamax bohemicus Stolley, 1916. Holotype. A: Dorsal view. B: Lateral view. C: Ventral view. D: View of anterior end of guard, $\times 1$.5. E: Ventral view showing granulation, $\times 2$ approx. F: Lateral view showing granulation, $\times 2$ approx.

Fig. 4. Actinocamax bohemicus Stolley, 1916. A: Dorsal view. B: Lateral view. C: Ventral view. D: View of anterior end of guard, $\times 3$ approx. E: View of middle part of dorsal field showing granulation, $\times 4$. The specimen was figured as Belemnitella plena var. strehlensis by Geinitz, 1872-1875, P1. 31: 13.

Fig. 5. Actinocamax bohemicus Stolley, 1916. A: Dorsal view. B: Lateral view. C: Ventral view. D: View of anterior end of guard, $\times 3$ approx. The specimen was figured as Belemnitella plena var. strehlensis by Geinitz, 1872-1875, Pl. 31: 14. 

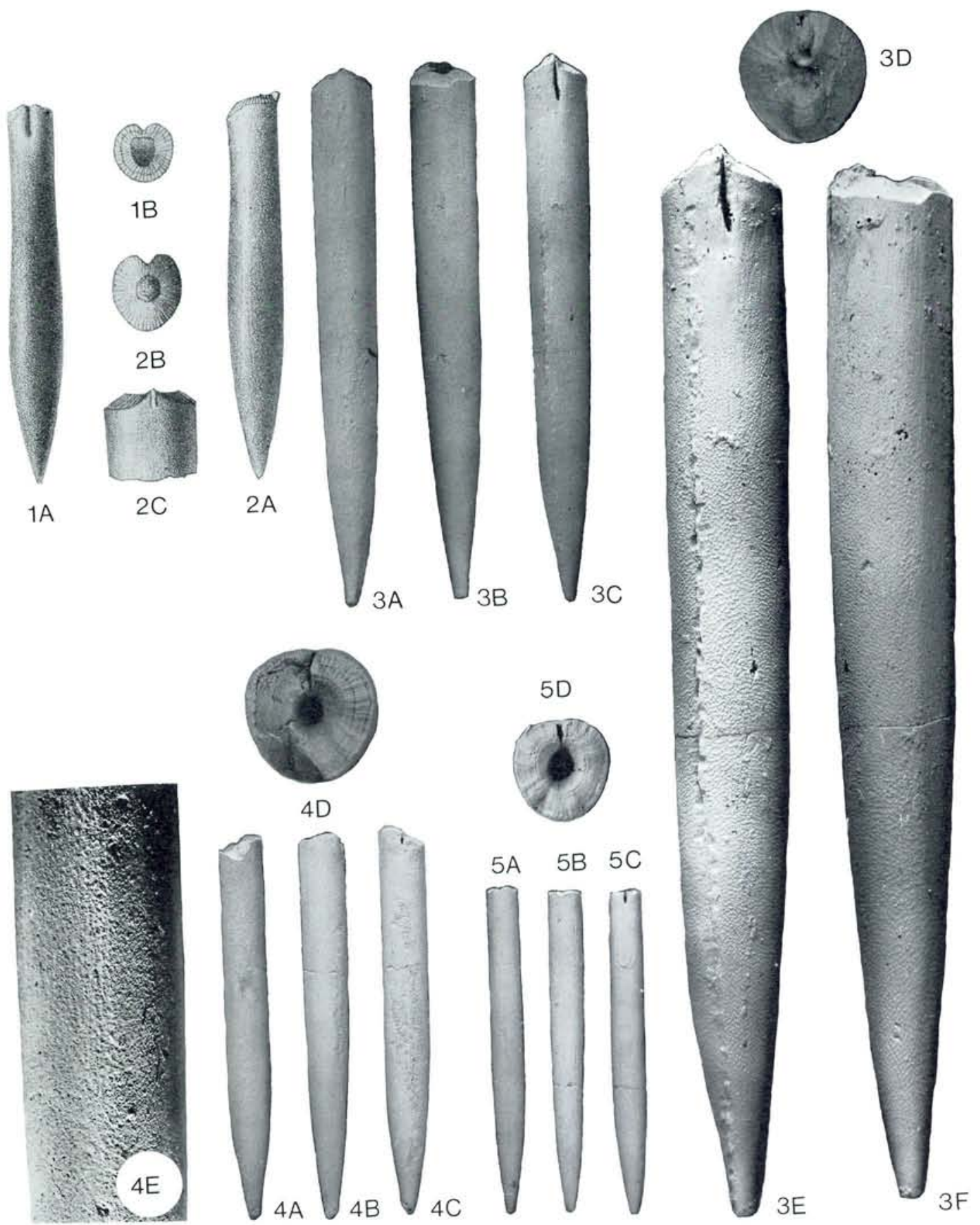
The present author, therefore, considers the shape of the guard to be a more significant taxonomic character than the presence of granules.

Family Belemnitellidae Pavlov, 1914

\section{Genus Actinocamax Miller, 1823}

Remarks: Naidin (1964) recognised three subgenera of the genus Actinocamax Miller, $A$. (Actinocamax), A. (Praeactinocamax), and $A$. (Paractinocamax) and two subgenera of the genus Gonioteuthis Bayle, G. (Gonioteuthis) and G. (Goniocamax); subgenera Praeactinocamax, $\mathrm{Pa}$ ractinocamax, and Goniocamax were new. The classification of Naidin is not followed here, because it is not logical from a phylogenetic point of view. In addition, some of the subgenera are superfluous, e.g., species belonging to $A$. (Actinocamax) and $A$. (Praeactinocamax) only differ by their size, and species referred to $A$. (Paractinocamax) by Naidin are closely related to species of the genus Belemnellocamax Naidin. Moreover, Naidin assigned the earliest members of the evolutionary lineage of Gonioteuthis (westfalica and westfalicagranulata) to G. (Goniocamax) in addition to other species such as medwedicicus, matesovae, intermedius, and lundgreni, while the later members of the Gonioteuthis lineage (granulata, granulataquadrata, and quadrata) were placed in $G$. (Gonioteuthis). The species described below and species from North America and Western Greenland earlier referred to $A c$ tinocamax by Jeletzky $(1950,1961)$ and Birkelund (1956) were tentatively assigned to $G$. (Goniocamax) by Naidin. Ernst \& Schulz (1974: 44) have also critized the classification of Naidin, and they suggested (1) that only the members of the evolutionary lineage: westfalica, westfalica- granulata, granulata, granulataquadrata, and quadrata should be placed in the genus Gonioteuthis; and (2) subgenus Goniocamax (type species Actinocamax lundgreni) should be elevated to a genus or considered a subgenus of Belemnitella d'Orbigny and only the lundgreni group and its ancestors should be assigned to Goniocamax.

The species referred to $G$. (Goniocamax) by Naidin (1964), apart from westfalica and westfalicagranulata, are referred to the genus Actinocamax in the present paper. The suggestion by Ernst $\&$ Schulz (1974) concerning the subgenus Goniocamax must await further studies and is outside the scope of this paper.

Actinocamax strehlensis (Fritsch \& Schlönbach, 1872)

Pl. 1, figs 1-2

1872 Belemnites strehlensis Fritsch \& Schlönbach: p. 8, P1. 16: 10-12 (non P1. 16: 17)

pars 1874 Belemnites strehlenensis Fritsch - Schlüter, p. 830

pars 1876 Belemnites strehlenensis Fritsch \& Schlönbach - Schlüter, p. 187, 222

pars 1894 Actinocamax strehlenensis (Fritsch \& Schlönbach) - Schlüter, p. 282

pars 1901-1903 Actinocamax strehlensis (Fritsch \& Schlönbach) - de Grossouvre, p. 782

1916 Actinocamax strehlensis (Fritsch) - Stolley, p. 102

1950 Actinocamax strelensis (Fritsch \& Schlönbach) - Jeletzky, p. 9

pars 1956 Actinocamax strehlensis (Fritsch) - Birkelund, p. 10

1959 Actinocamax strehlensis (Frix) - Soukup, p. 86

1961 Actinocamax strehlensis (Fritsch \& Schlönbach) - Jeletzky, p. 514

1964 Actinocamax strehlensis (Fritsch) - Naidin, p. 141

1965 Actinocamax strehlensis (Fritsch) - Makhlin, p. 26

1966 Actinocamax strehlensis (Frič) - Klein \& Soukup, p. 500

Plate 2. All figures are of matural size unless otherwise indicated. Specimens are coated with ammonium chloride.

Fig. 1. Actinocamax bohemicus Stolley, 1916. The specimen came from the locality Little Weighton, Humberside, England. National grid reference: SE 9817 3328. A: Dorsal view. B: Lateral view. C: Ventral view. D: View of anterior end, $\times 2$ approx.

Fig. 2. Actinocamax bohemicus Stolley, 1916. MGUH 15970. The specimen came from the locality Särdal, Sweden. A: Dorsal view. B: Lateral view. C: Ventral view. D: View of anterior end, $\times 2$ approx. E: View of ventral side of guard showing granulation, $\times 4$.

Fig. 3. Actinocamax paderbornensis Schlüter, 1894. Holotype. A: Dorsal view. B: Lateral view. C: View of anterior end of guard, $\times 2$ approx.

Fig. 4. Actinocamax esseniensis n. sp. Holotype. MGUH 15971. A: Dorsal view. B: Lateral view. C: Ventral view. D: View of 15971 anterior end of guard, $\times 2$ approx. E: View of split anterior end of guard showing internal characters, $\times 1.5$. 

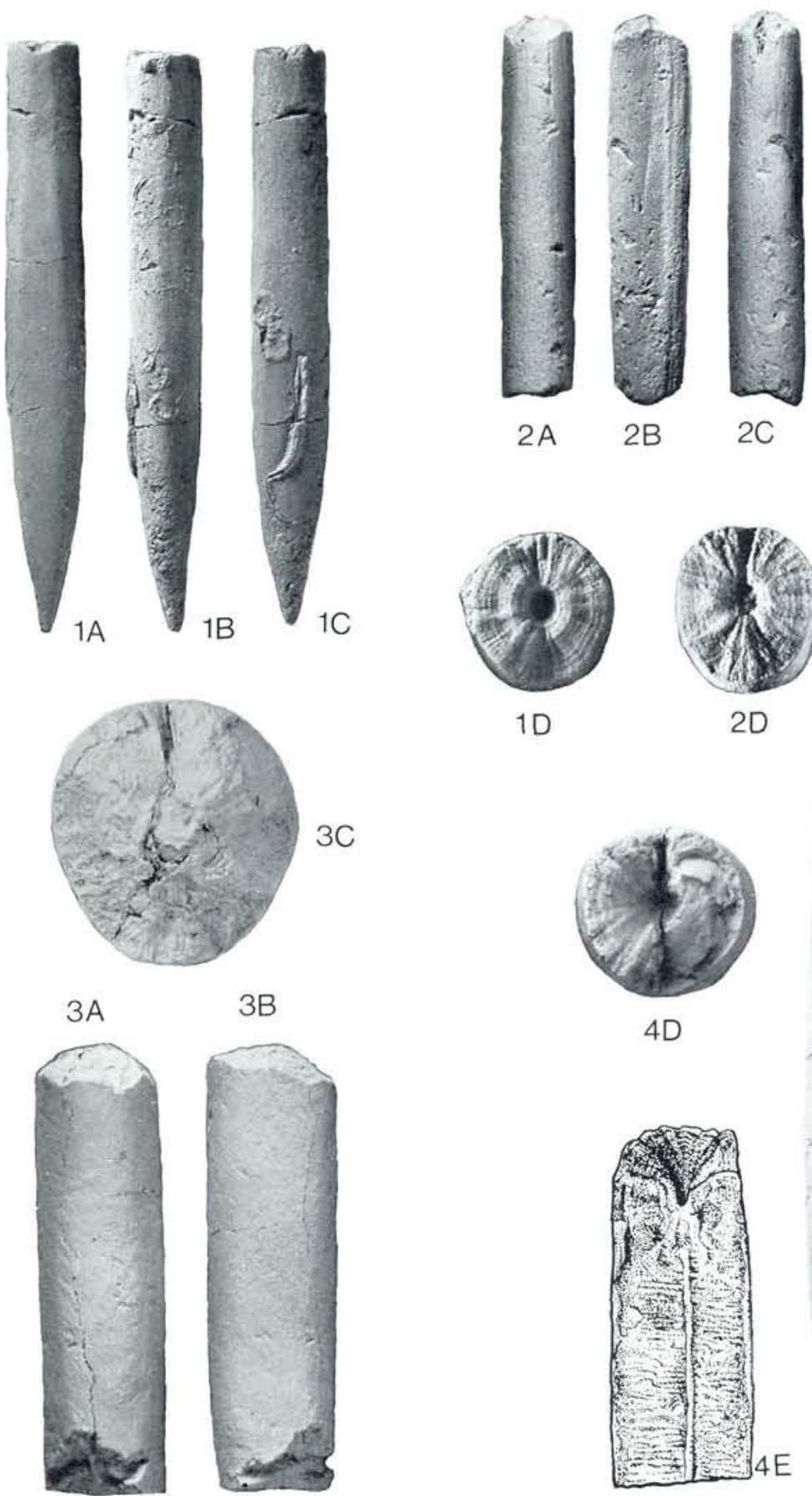

3B

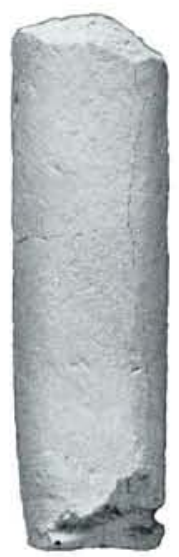

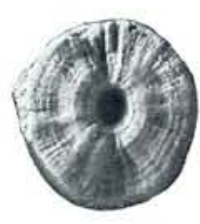

$1 \mathrm{D}$

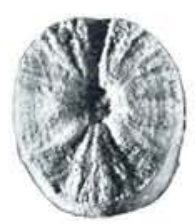

20
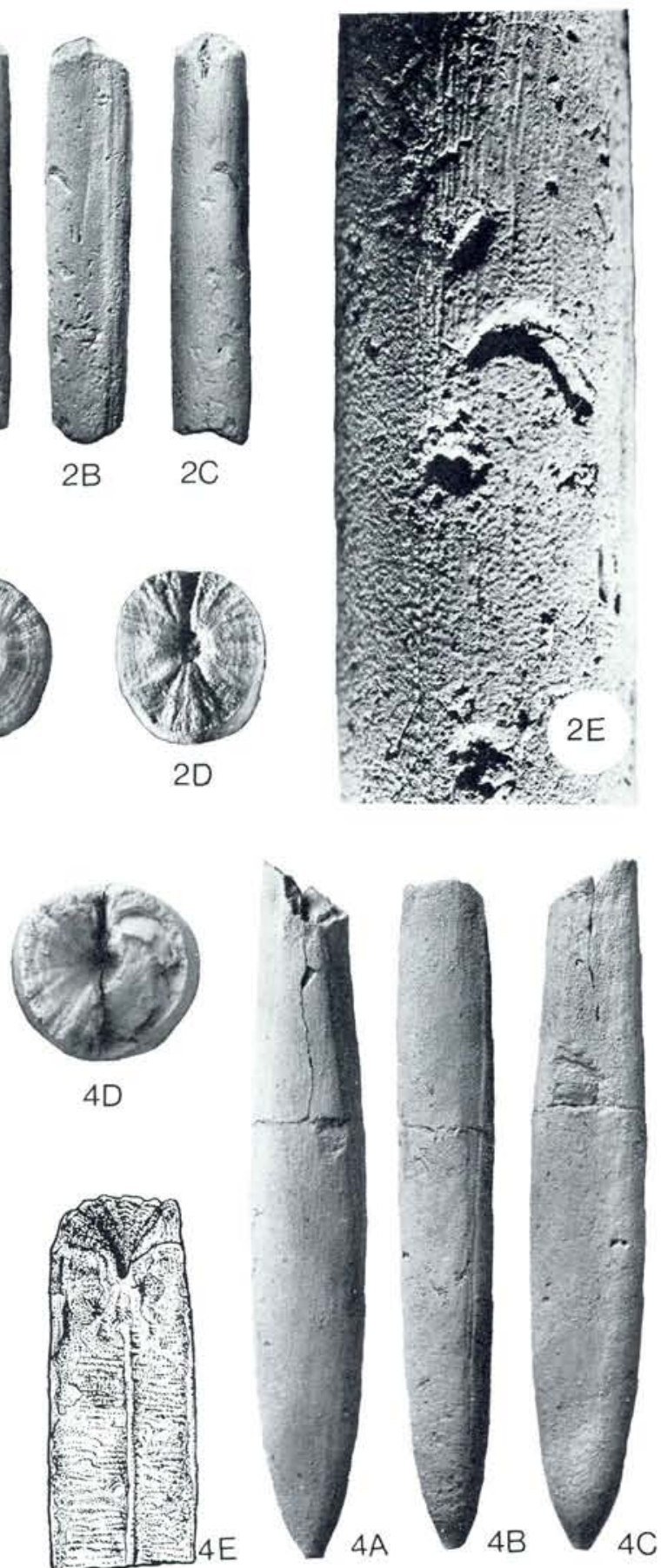
1975a Actinocamax strehlensis (Fritsch \& Schlönbach) - Christensen, p. 27

1976 Actinocamax strehlensis (Fritsch \& Schlönbach) - Christensen, p. 17

1981 Actinocamax strehlensis (Fric) - Tröger, p. 18

Type: The specimen figured by Fritsch \& Schlönbach (1872, Pl. 16: 10) was designated as lectotype for the species by Birkelund (1956: 10). The figure of the specimen is reproduced as fig. 1 on plate 1 in the present paper. The lectotype and the paralectotype appear to be lost. The two specimens came from the Teplitzer Schichten at Strehlen near Dresden. According to Prescher (1981) this formation can be referred to the Upper Turonian, Zone of $I$. schloenbachi. This zone is assigned to the Early Coniacian in the present paper (see discussion above and fig. 1).

Description: The length of the two guards is about $55 \mathrm{~mm}$. The guard is short and stout and lanceolate in ventral and lateral views with the maximum diameter situated in the posterior third of the guard. The anterior part of the guard either has a shallow pseudoalveolus (lectotype) or is provided with a very low cone-shaped alveolar fracture with a pit in its center (paralectotype). The fracture is sharply demarcated from the surface of the guard and asymmetrical, the dorsal side being more incised than the ventral side. A 4 $\mathrm{mm}$ long ventral furrow is present in the lectotype. The cross-section of the anterior part of the guard is subtriangular with the dorso-ventral diameter exceeding the lateral diameter. The two specimens apparently do not have dorso-lateral double furrows, dorso-lateral depressions, single lateral furrows, granulation, striation, or vascular markings.

Discussion: $A$. strehlensis is characterized by being short and stout, and markedly lanceolate both in ventral and lateral views with the maximum diameter situated in the posterior third of the guard. $A$. strehlensis differs from $A$. bohemicus by its shape of the guard. A. strehlensis shows some resemblance to $A$. intermedius with respect to shape of guard. However, $A$. intermedius differs from $A$. strehlensis in the development of the anterior part of the guard. The anterior end generally is poorly calcified in $A$. intermedius resulting in specimens showing exfoliation of the anterior end. Moreover, $A$. strehlensis does not have any

Table 1. Measurements in mm of critical characters and ratios of Actinocamax bohemicus (Fritsch \& Schlönbach), A. paderbornensis Schlüter and $A$. esseniensis n. sp. 1: Holotype of A. bohemicus. 2 \& 3: Geinitz' specimens of Belemnitella plena var. strehlensis. 4: English specimen. 5: Swedish specimen. 6: Holotype. 7: Holotype. L: length of guard. $\mathrm{D}=$ depth of pseudoalveolus. DVDP $=$ dorso-ventral diameter at protoconch. $\mathrm{LDP}=$ lateral diameter at protoconch. DVDAF $=$ dorso-ventral diameter at alveolar fracture. LDAF = lateral diameter at alveolar fracture. MLD = maximum lateral diameter. $\mathrm{LVF}=$ length ventral furrow. + estimated.

\begin{tabular}{|c|c|c|c|c|c|c|c|c|c|c|c|c|}
\hline Specimens & $\mathrm{L}$ & $\mathrm{D}$ & DVDP & LDP & DVDAF & LDAF & MLD & LVF & $\frac{\text { MLD }}{\text { LDAF }}$ & $\frac{\text { MLD }}{L D P}$ & $\frac{L}{D}$ & $\frac{L}{M L D}$ \\
\hline \multicolumn{13}{|c|}{ Actinocamax bohemicus Stolley, 1916} \\
\hline 1. & 77.7 & - & & & 9.4 & 8.8 & 8.9 & 6.2 & 1.0 & & & 8.7 \\
\hline 2. & $56^{+}$ & 3.5 & 6.4 & 6.1 & & & 6.1 & 1.6 & & 1.0 & 16.0 & 9.2 \\
\hline 3. & $47^{+}$ & 2.2 & 4.6 & 4.4 & & & 4.6 & 1.7 & & 1.0 & 21.4 & 10.2 \\
\hline 4. & $68^{+}$ & - & & & 8.6 & 8.2 & 9.1 & - & 1.1 & & & 7.5 \\
\hline 5. & - & - & & & 9.1 & 8.0 & 8.6 & 3.0 & 1.1 & & & \\
\hline
\end{tabular}

Actinocamax paderbornensis Schluiter, 1894
6.
15.514 .5
14.9
1.0

Actinocamax esseniensis n.sp.

\begin{tabular}{llllllllll}
7. & $78^{+}$ & 6.1 & 10.0 & 10.0 & 12.9 & - & 1.3 & 12.8 & 6.0 \\
\hline
\end{tabular}


surface markings in contrast to $A$. intermedius. $A$. strehlensis differs from juvenile specimens of $A$. plenus in being more stout and lanceolate in ventral and lateral views.

Actinocamax bohemicus Stolley, 1916

PI. 1, figs 3-5; Pl. 2, figs 1-2

1872 Belemnites strehlensis Fritsch \& Schlönbach, p. 19, Pl. 16: 17 (non Pl. 16: 10-12)

1872-1875 Belemnitella plena var. strehlensis FritschGeinitz, p. 180, Pl. 31: 13-14 (non Pl. 31: 15)

pars 1874 Belemnites strehlenensis Fritsch-Schlüter, p. 830,849

pars 1876 Belemnites strehlenensis Fritsch \& Schlönbach - Schlüter, p. 187, 222

1889 Belemnites strehlensis Fric - Frič, p. 72, fig. 46

pars 1894 Actinocamax strehlenensis (Fritsch \& Schlönbach) - Schlüter, p. 282

pars 1901-1903 Actinocamax strehlensis (Fritsch \& Schlönbach) - de Grossouvre, p. 782

1916 Actinocamax bohemicus Stolley: p. 102

1950 Actinocamax bohemicus Stolley - Jeletzky, p. 5

1956 Actinocamax bohemicus Stolley - Birkelund, p. 8

pars 1956 Actinacamax strehlensis (Fritsch) - Birkelund, p. 10

1961 Actinocamax bohemicus Stolley - Jeletzky, p. 519

1964 Actinocamax bohemicus Stolley - Naidin, p. 142

1965 Actinocamax bohemicus Stolley - Makhlin, p. 26

1973 Actinocamax bohemicus Stolley - Christensen, p. 137

?1973 Actinocamax? sp. indet. - Christensen, p. 137, Pl. 11: 4-5

1975a Actinocamax bohemicus Stolley - Christensen, p. 27

1976 Actinocamax bohemicus Stolley - Christensen, p. 117

Type: The specimen figured as Belemnites strehlensis by Fritsch \& Schlönbach (1872, Pl. 16: 17) is the holotype (Stolley 1916: 102). The holotype came from the Teplitzer Schichten at Kostic in Bohemia. According to Prescher (1981) The Teplitzer Schichten can be assigned to the Upper Turonian, Zone of $I$. schloenbachi. In the present paper this zone is put in the Early Coniacian (see previous discussion and fig. 1). The specimen is housed in the Narodni Museum in Praha from which a resin cast was obtained for study.

Material studied: (1) A cast of the holotype. (2) Two specimens referred to as $B$. plena var. strehlensis by Geinitz (1872-1875, P1. 31: 1314). The specimens are housed in Staatliches
Museum für Mineralogie und Geologie, Dresden, DDR, from where they were obtained for study, (3) One specimen from the locality Särdal in Sweden housed in Geological Museum, Copenhagen. (4) One specimen from the locality Little Weighton, Humberside, Yorkshire, England housed in Institute of Geological Sciences, London, (5) Three incomplete granulated specimens in which the anterior part of the guard is not preserved from the locality Särdal in Sweden may also belong to $A$. bohemicus. The three specimens were described and figured by Christensen (1973: 137-138, Pl. 11: 4-5).

Diagnosis: A slender medium-sized Actinocamax which is cylindrical or subcylindrical in ventral view and conical in lateral view. The guard has anteriorly either a low cone-shaped alveolar fracture, or is flat with a shallow pit in its center, or has a shallow pseudoalveolus. Dorso-lateral longitudinal depressions, dorso-lateral double furrows and single lateral furrows may be present. The guard may be strongly granulated, weakly granulated or not granulated at all. Vascular markings are not developed.

General description: Measurements of critical characters of the five specimens are listed in Table 1 . The guard is medium-sized, cylindrical or subcylindrical in ventral view and conical in lateral view. The guard is slightly flattened ventrally and compressed laterally in its adoral part. A mucro is not present but the apical end of the guard is acute.

Dorso-lateral longitudinal depressions are weakly developed, while dorso-lateral double furrows, single lateral furrows, and longitudinal striae may be present. Vascular markings are not developed. The guard may carry granules which forms corrugated transverse lines on the ventral and lateral sides, except in connection with longitudinal striae, where the granules appear to be arranged in longitudinal rows. On the dorsal side the granules may be scattered or appear to be arranged in longitudinal rows.

The cross-section of the anterior part of the guard is subtriangular to oval. The guard has anteriorly either a low cone-shaped alveolar fracture, or is flat with a shallow pit in its center, or has a shallow pseudoalveolus. A ventral furrow normally is present. 
Remarks: Since some of the material under discussion was described very shortly or inadequately by earlier workers and new observations have been made after preparation, some additional remarks will be provided.

(1) Holotype. The surface of the guard seems to be well-preserved and has granules on all surfaces, except the anterior third of the dorsal side and immediately around the ventral furrow. On the ventral and lateral sides the granules form corrugated transverse lines. The granules are scattered on the posterior dorsal side of the guard, while on the ventral side immediately below the ventral furrow, in connection with longitudinal striae, the granules appear to be arranged in longitudinal rows. The ventral furrow is very distinct.

(2) The two specimens of $A$. plenus var. strehlensis described by Geinitz (1872-1875). When the specimens were received for study they were embedded in matrix. They were freed from matrix in Copenhagen before study. The surface of the guard of the small specimen is relatively wellpreserved, while the surface, notably the ventral side, of the large specimen is weathered. In both specimen the outermost apical part of the guard is missing; the length of the guards are estimated to be $56 \mathrm{~mm}$ and $47 \mathrm{~mm}$ respectively.

The large specimen has granules on the middle part of the dorsal field, and they are placed in longitudinal rows. The guard has anteriorly a shallow pseudoalveolus the depth of which is $\mathbf{3 . 5}$ $\mathrm{mm}$. The walls of the central part of the pseudoalveolus are slightly convex and the walls of the marginal part are virtually flat. The guard has a deep, short, ventral furrow.

The small specimen is juvenile and the only surface markings consist of very faintly developed dorso-lateral depressions and longitudinal striae ventrally. The guard has a shallow pseudoalveolus anteriorly the depth of which is $2.7 \mathrm{~mm}$. The walls of the ventral part of the pseudoalveolus are slightly convex, while the walls of the marginal part are virtually flat. The guard has a deep, short, ventral furrow.

(3) The English specimen. The surface of the guard, notably the left side, is weathered. The anterior part of the guard is flat with a shallow pit in its center, and a ventral furrow is not present.

(4) The Swedish specimen. The surface of the guard is weathered. Dorso-lateral longitudinal depressions, dorso-lateral double furrows and single lateral furrows are present. The dorsal field and the ventral side are striated. The guard has granules on the ventral side, and they appear to form corrugated transverse lines, except in connection with longitudinal striae, where the granules appear to be arranged in longitudinal rows. Anteriorly the guard has a low cone-shaped alveolar fracture, and a deep, short, ventral furrow.

Discussion: The species is distinguished by its shape which is cylindrical to subcylindrical in ventral view and conical in lateral view. Some specimens may carry granules; three out of five specimens discussed above have granules. The species differs from most other species of $A C$ tinocamax by its shape. The affinity to $A$. paderbornensis and $A$. manitobensis is discussed below.

Stratigraphy: The holotype is of Early Coniacian age (Zone of $I$. schloenbachi). The two specimens of Geinitz came from the Strehlener Schichten (Pläner Limestone) at Strehlen in Saxony, which according to Prescher (1981) is correlatable with the Bohemian Teplitzer Schichten; that is Early Coniacian, Zone of $I$. schloenbachi. On the other hand, Tröger \& Wolf (1960) recorded I. costellatus and $I$. inconstans from the Strehlener Schichten. According to Tröger (1981b, text, not fig. 5) I. costellatus costellatus appears in the Upper Turonian and $I$. inconstans in the Early Coniacian. Therefore, the Strehlener Schichten may be referred to the upper Turonian-lower Coniacian boundary strata. The English specimen was collected loose in the working quarry at Little Weighton. Humberside, Yorkshire. It probably came from near the base of the local 'Hagenowia rostrata Zone', and this zone can be correlated with the German I. koeneni Zone (C. J. Wood, pers. comm. 1979). The Swedish specimen was also collected loose at the Särdal locality on the west coast of Sweden. The locality was described by Bergström et al. (1973) and the belemnites were described by Christensen (1973). Christensen concluded that the belemnites could be assigned partly to the Cenomanian and partly to the zone comprising the upper Lower and lower Middle Santonian. Birkelund (1973), however, described a single specimen of the ammonite Pseudopuzosia sp., which was found in a phosphatized rock fragment at Särdal. Wright (1979) 
referred the specimen to the new species Lewesiceras woodi Wright, which otherwise is known from the English Chalk Rock of late Turonian age (lower part of Holaster planus Zone). It is believed that the specimen of $A$. bohemicus from Särdal has the same age as $L$. woodi.

In summary it can be concluded that $A$. bohemicus occurs in the late Turonian-Middle Coniacian.

Actinocamax paderbornensis Schlüter, 1894 Pl. 2, fig. 3

1894 Actinocamax paderbornensis Schlüter: p. 286 1901-1903 Actinocamax paderbornensis Schlüter - de Grossouvre, p. 782

1916 Actinocamax paderbornensis Schlüter - Stolley, p. 102

1950 Actinocamax paderbornensis Schlüter - Jeletzky, p. 10

1956 Actinocamax paderbornensis Schlüter - Birkelund, p. 8

1961 Actinocamax paderbornensis Schlüter - Jeletzky, p. 520

1964 Actinocamax paderbornensis Schlüter - Naidin, p. 142

1965 Actinocamax paderbornensis Schlüter - Makhlin, p. 26

1973 Actinocamax paderbornensis Schlüter - Christensen, p. 138

1975a Actinocamax paderbornensis Schlüter - Christensen, p. 27

1976 Actinocamax paderbornensis Schlüter - Christensen, p. 117

Type: The only known specimen of $A$. paderbornensis is the holotype by monotypy. It was described, but not figured, by Schlüter (1894). It came from the uppermost part of the 'Cuvieri-Pläner' at the water works east of the town of Paderborn in the eastern part of the Münster Basin. The 'Cuvieri-Pläner' is referable to the uppermost Turonian (Oberturon 4, Zone of $I$. schloenbachi) according to Arnold (1964a). In the present paper this zone is put in the Early Coniacian (fig. 1). According to Wiedmann (1979) the 'Cuvieri-Pläner' includes both the uppermost Turonian and the Lower Coniacian sensu gallico. The specimen is housed in the Geologisch-Paläontologisches Institut, Bonn, GDR, from where it was obtained for study.

Description: Measurements of critical characters are listed in Table 1. The posterior part of the guard is missing, and the length of the fragment is $53.5 \mathrm{~mm}$. The surface of the guard is not wellpreserved.
The guard appears to have been very large. In ventral view it is subcylindrical and in lateral view it is high conical. The guard is slightly flattened ventrally, this flattening being most pronounced in the posterior part, and the adoral end is compressed.

The surface of the guard is smooth, except for a longitudinal striation on the ventral, most posterior part of the guard. Dorso-lateral longitudinal depressions, dorso-lateral double furrows and single lateral furrows are not developed.

The cross-section of the anterior end is subtriangular and anteriorly the guard has a low cone-shaped alveolar fracture. There seems to be a small pit in its center; this pit, however, is apparently filled with matrix. The alveolar fracture is asymmetrical, the dorsal side being more incised than the ventral side, and it is sharply demarcated from the surface of the guard. The alveolar cone exhibits radial ridges and has a ventral embayment that reaches to the center of the cone. A ventral furrow is not present.

Remarks: According to Schlüter (1894: 282) the guard has "scattered grain-like elevations..., which generally are equally spaced" on a small area of the dorsal side. I have not been able to recognise these granules on the surface of the guard.

Discussion: A. paderbornensis is, notably, distinguished by its large size, shape of guard, and structure of anterior end. It differs from all other species of Actinocamax in the North European Province by the size of the guard and from most other species of Actinocamax by the shape of the guard. The affinity to $A$. bohemicus and $A$. manitobensis is discussed below.

Affinity between $A$. bohemicus, $A$. paderbornensis, and $A$. manitobensis

$A$. bohemicus and $A$. paderbornensis show similarities with respect to the shape of the guard and the structure of the anterior end, but $A$. paderbornensis is larger than $A$. bohemicus.

$A$, bohemicus and $A$. paderbornensis show resemblance in various characters (e.g. shape of guard, structure of anterior end and in the case of 
A. paderbornensis also size of the guard) to some specimens of $A$. manitobensis (Whiteaves, 1889) as understood by Jeletzky $(1950,1961)$ from the Turonian of North America. A. manitobensis was revised by Jeletzky $(1950,1961)$ on the basis of a small number of specimens the stratigraphic control of which was very poor. Jeletzky (1950, 1961) suggested that the stratigraphically poorly located material was of late Turonian age. This suggestion was to some extent supported, at least for the specimens from Kansas, by Hattin (1962) who recorded a single specimen of $A$. manitobensis from the Fairport Member of the Carlile Shale Formation. The Fairport Member has also yielded the ammonite Collignociceras woolgari and various inoceramid species, and the member is referred to the Middle Turonian by Kauffman (1977). It is, however, highly probable that the material of $A$. manitobensis from North America described by Jeletzky $(1950,1961)$ spans more than one zone.

Jeletzky $(1950,1961)$ distinguished four varieties of $A$. manitobensis in addition to the typical form. Varieties trehernensis Jeletzky, 1950 and lawrencii Jeletzky, 1950 differ from the typical form of $A$. manitobensis by the development of the anterior end. $A$. manitobensis var. trehernensis has an alveolar fracture anteriorly; $A$. manitobensis f. typ. has a shallow pseudoalveolus; and A. manitobensis var. lawrencii has a deeper pseudoalveolus than the typical form. The three forms all have guards which are more or less lanceolate in ventral view. A. manitobensis var. spicularis Jeletzky, 1961 is characterised by being subcylindrical in ventral view, cone-shaped in lateral view, and by having an alveolar fracture anteriorly, while $A$. manitobensis var. kansanus Jeletzky, 1961 morphologically is transitional between the varieties trehernensis and spicularis (Jeletzky 1961). However, according to statements by Jeletzky (e.g. 1950: 6-7 and 1961: 513-514) the varieties are nothing but morphological variants of $A$. manitobensis, and, therefore, following $\S 45$ of the Code, they are to be regarded as of infrasubspecific rank. In order to accomodate all the varieties of $A$. manitobensis, Jeletzky (1961: 507) proposed a very broad diagnosis for the species. In fact, the diagnosis is so comprehensive that it is not workable, because many species of Actinocamax could be classified as $A$. manitobensis. A. manitobensis needs a revi- sion based on stratigraphically well-documented material.

A. manitobensis var. spicularis is somewhat similar to $A$. bohemicus with respect to shape of guard and structure of anterior end, but differs by the size of the guard. The variety is much larger than $A$. bohemicus. Jeletzky (1961: 514) tentatively identified the two specimens of $A$. plenus var. strehlensis sensu Geinitz (1872-1875), which are assigned to $A$. bohemicus in the present paper, with $A$. manitobensis var. spicularis. $A$. paderbornensis is of the same size as $A$. manitobensis and resembles some specimens of $A$. manitobensis as figured by Jeletzky (1950). It seems unwise, however, at present to identify the European forms with North American representatives of $A$. manitobensis sensu Jeletzky (1950, 1961) until this species has been revised.

Actinocamax esseniensis n. sp.

Pl. 2, fig. 4

Type: The only known specimen is the holotype by monotypy. According to Dr. C. Frieg (pers. comm. 1977) the specimen was found in the brick-yard of the Hubert-Mine at Essen-Frillendorf in the SW part of the Münster Basin. The The brick-yard was closed in 1960 and is now partly covered by rubbish and partly flooded. The locality has not been described in the litterature. However, on map 2 enclosed in the paper by Arnold (1964b), the brick-yard was situated south of the 'Schact-Hubert' at the ' $f$ ' in Frillendorf $\left[51^{\circ} 28^{\prime} \mathrm{N}, 7^{\circ} 03^{\prime} \mathrm{E}\right]$. The specimen came from a glauconitic sandy marl, the age of which is Early Coniacian, Zone of $I$. schloenbachi. All data on the specimen were kindly provided by Dr. C. Frieg, Bochum, who collected the specimen and placed it at my disposal. The holotype is deposited in Geological Museum, Copenhagen.

Description: Measurements of critical characters are listed in Table 1. The specimen is almost complete; only the outermost part of the mucro and the right part of the alveolar wall are missing. The length of the guard is estimated to have been $78 \mathrm{~mm}$. The surface on the guard, and, notably, the dorsal and ventral parts of the alveolar end of the guard have been affected by weathering.

Viewed ventrally the guard is lanceolate with the maximum lateral diameter situated in the 


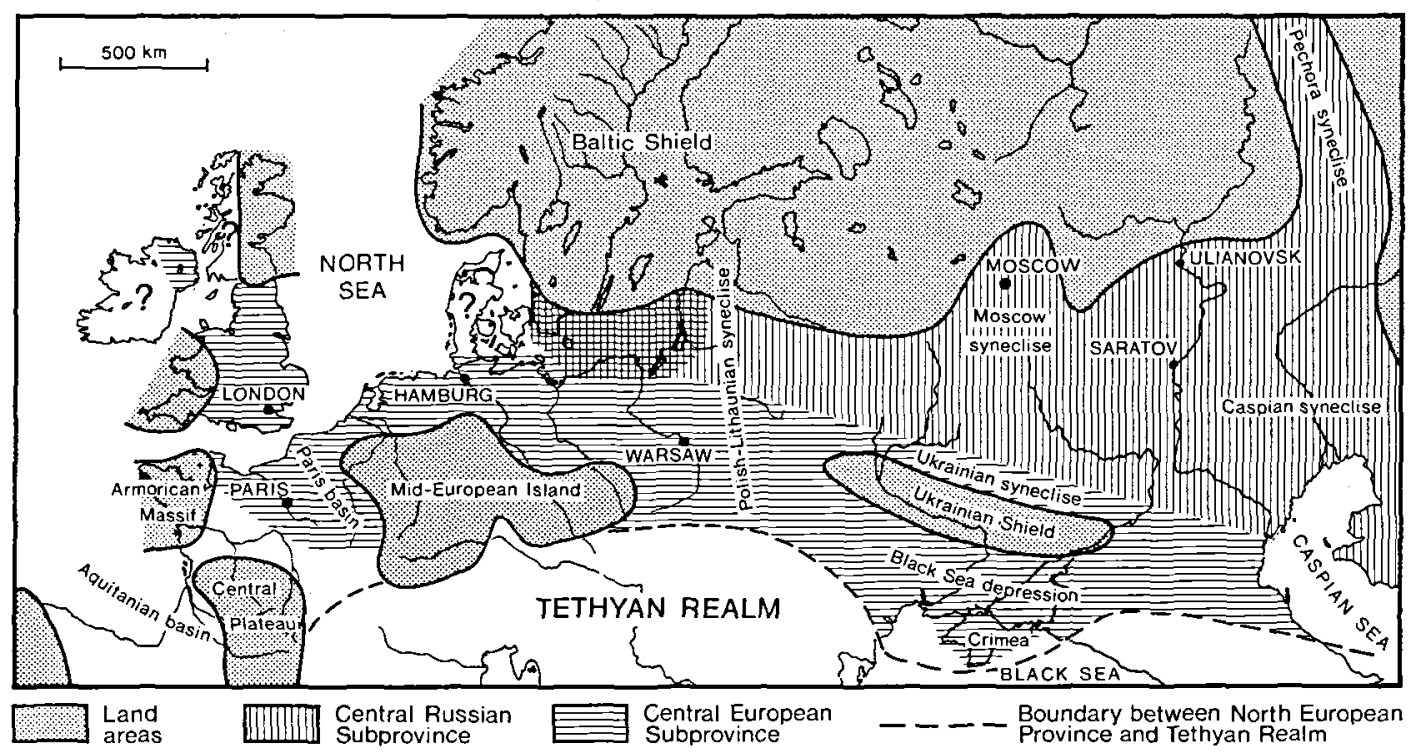

Fig. 2. Distribution of Late Cretaceous biogeographical units in Europe based on belemnites. Late Cretaceous land and sea areas represent maximum inundation for all stages. It should be stressed that the boundaries of land areas are not reliable in detail and the biogeographical units are typically gradational in character (after Christensen 1976).

middle part of the guard, and viewed laterally it is very slightly lanceolate to subcylindrical. The guard is flattened ventrally along its entire length. Moreover, the posterior half of the dorsal side of the guard is also flattened. The mucro is indistinctly separated from the guard.

Dorso-lateral longitudinal depression $\lrcorner$ are welldefined and continue posteriorly in distinct, straight, dorso-lateral double furrows that proceed almost to the apex. Vascular imprints and single lateral furrows cannot be seen. Part of the dorsal field appears to be provided with longitudinal striae.

The guard has a shallow pseudoalveolus, and the crossection of the pseudoalveolus is subtriangular. The 'Riedel-Quotient' (length of guard divided by depth of the pseudoalveolus) is 12.8. The walls of the pseudoalveolus are slightly convex and show concentric growth layers and radial ridges; the walls are not covered by the white layer sensu Christensen (1975a: 29). A single conellus is present in the middle part of the pseudoalveolus. The ventral edge of the pseudoalveolus has a v-shaped notch the length of which is $7 \mathrm{~mm}$. It is uncertain if the v-shaped notch is an original character, or if it was formed by weathering of the ventral fissure. The protoconch is not well-defined. The inner end of the supposed bottom of the ventral fissure starts ca. $1.5 \mathrm{~mm}$ above the most posterior part of the pseudoalveolus; its shape is convex and the outer end terminates ca. $0.7 \mathrm{~mm}$ anterior to the inner end. The ontogeny of the specimen is not known, since only the anterior half of the guard was split.

Discussion: $A$. esseniensis n. sp. differs from $A$. bohemicus and $A$. paderbornensis by its lanceolate shape in ventral view, ventral flattening, and deeper pseudoalveolus. It differs from $A$. strehlensis by the size of the guard and by having a deeper pseudoalveolus. Moreover, the maximum lateral diameter is situated in the middle part of the guard in $A$. esseniensis $\mathrm{n}$. $\mathrm{sp}$. while it is situated in the lower third in A. strehlensis. $A$. esseniensis n. sp. shows resemblance to $A$. coronatus (Makhlin, 1965), A. intermedius Arkhangelsky, 1912, A. medwedicicus (Naidin, 1964), and Gonioteuthis westfalica mujnakensis Naidin, 1964, and a study of further material of these forms may show that some of the taxa should be placed in synonymy.

$A$. coronatus differs from $A$. esseniensis n. sp. by being more slender, less markedly lanceolate in ventral view, only slightly flattened ventrally, and by having a more shallow pseudoalveolus. $A$. intermedius and $A$. esseniensis n. sp. are some- 
what similar with respect to size, shape, and the ventral flattening of the guard. However, the anterior part of the guard is poorly calcified in $A$. intermedius resulting in specimens which generally have an exfoliated anterior end. $A$. medwedicicus differs by having a more shallow pseudoalveolus, the cross-section of which is oval. G. westfalica mujnakensis, which probably should be placed in the $A$. lundgreni group owing to its lanceolate shape in ventral view and markedly ventral flattening (Christensen 1975a,
1976), differs from A. esseniensis n. sp. by being smaller and having a more shallow pseudoalveolus.

\section{Palaeobiogeography and evolutionary trends}

Christensen (1975a, 1976) reviewed the palaeobiogeography of the Late Cretaceous belemnites of Europe. Two subprovinces within the North

\begin{tabular}{|c|c|c|c|c|c|c|c|c|c|c|c|c|c|c|c|}
\hline \multirow{2}{*}{ 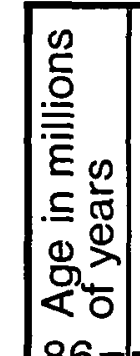 } & \multirow[b]{2}{*}{ 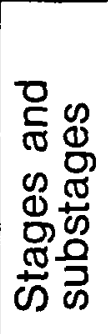 } & \multirow[b]{2}{*}{ Zones } & \multicolumn{12}{|c|}{ Actinocamax } & \multirow{2}{*}{ 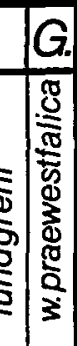 } \\
\hline & & & 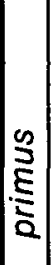 & 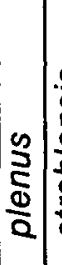 & 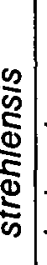 & & & 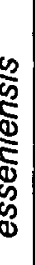 & 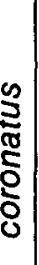 & $\frac{\substack{9 \\
\frac{\pi}{2}}}{\overbrace{0}^{2}}$ & $\stackrel{\Xi}{\Xi}$ & 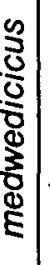 & 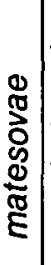 & 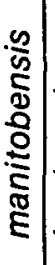 & \\
\hline \multirow[t]{4}{*}{$86-$} & \multirow{4}{*}{$\frac{U}{Z}-$} & $\begin{array}{l}\text { Inoceramus } \\
\text { subquadratus }\end{array}$ & & & & & & & & & & & & & \\
\hline & & $\begin{array}{l}\text { Inoceramus } \\
\text { involutus }\end{array}$ & & & & & & & & & & & & & \\
\hline & & $\begin{array}{l}\text { Inoceramus } \\
\text { koeneni }\end{array}$ & & & & & & & & & & & & & \\
\hline & & $\begin{array}{l}\text { Inoceramus } \\
\text { schloenbachi }\end{array}$ & & & & & 0 & & & & & & I & & \\
\hline \multirow{3}{*}{$87-$} & \multirow{3}{*}{ 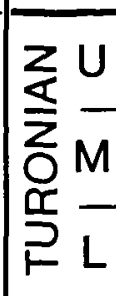 } & $\begin{array}{l}\text { Inoceramus } \\
\text { costellatus }\end{array}$ & & & & & ? & & & & & & & $?$ & \\
\hline & & $\begin{array}{l}\text { Inoceramus } \\
\text { lamarcki }\end{array}$ & & & & & & & & & & & & & \\
\hline & & $\begin{array}{l}\text { Inoceramus } \\
\text { labiatus }\end{array}$ & & & & & & & & & & & & $?$ & \\
\hline \multirow{4}{*}{$90-$} & \multirow{4}{*}{ 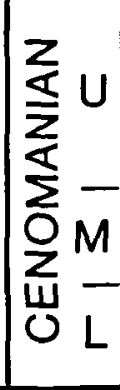 } & $\begin{array}{l}\text { Sciponoceras } \\
\text { gracile }\end{array}$ & & & & & & & & & & & & & \\
\hline & & $\begin{array}{l}\text { Eucalycoceras pentagonum/ } \\
\text { Calycoceras naviculare }\end{array}$ & & & & & & & & & & & & & \\
\hline & & $\begin{array}{l}\text { Acanthoceras } \\
\text { rhotomagense }\end{array}$ & $?$ & & & & & & & & & & & & \\
\hline & & $\begin{array}{l}\text { Mantelliceras } \\
\text { mantelli }\end{array}$ & & & & & & & & & & & & & \\
\hline
\end{tabular}

Fig. 3. Diagram showing the stratigraphical distribution of Cenomanian, Turonian, and Coniacian belemnites belonging to Belemnitellidae. The subdivision of the Cenomanian is based on Rawson et al. (1978). For the subdivision of the Turonian and Coniacian, see fig. 1. 
European Province were recognised: the Central Russian and the Central European Subprovinces (fig. 2). The two subprovinces are well-defined in the late Coniacian-Early Campanian and characterized by independently evolving belemnite lineages; the Gonioteuthis stock inhabited the Central European Subprovince and the $B e$ lemnitella stock (including $A$. lundgreni) inhabited the Central Russian Subprovince. In other periods of the Late Cretaceous the subprovinces are less distinct or may disappear completely.

A. primus from the Early and Middle Cenomanian (fig. 3 ) is the first species of the family Belemnitellidae, which characterizes the North Temperate Realm, and this species is known mainly from the Central Russian Subprovince. In the same period species of the Tethyan belemnite genera Neohibolites Stolley and Parahibolites Stolley of the family Belemnopseidae Naef are recorded from the Central European Subprovince (Combémorel et al. 1981). A. plenus from the Late Cenomanian, which is closely related to and probably evolved from $A$. primus (Jeletzky 1948), has been recorded from most parts of the North European Province. After the extinction of the genus Neohibolites in the Middle Cenomanian the genus Actinocamax, exemplified by $A$. plenus, expanded its area of distribution to the south.

In the Turonian and Early Coniacian belemnites have a very restricted distribution in the North European Province. In the Central Russian Subprovince belemnites occur almost exclusively in the Volga region and adjacent areas (Naidin 1981), and the following species are recorded: $A$. intermedius, $A$. medwedicicus, $A$. matesovae, $A$. coronatus, $A$. planus, and " $A$ ". surensis in addition to various subspecies of $A$. verus. Only $A$. intermedius is common while the other species occur infrequently. The late Turonian-early Coniacian belemnites from the Central European Subprovince are described above. They are extremely rare but widely distributed in the western part of the subprovince. Two specimens are recorded from England, two specimens from the Münster Basin in West Germany, one specimen from southern Sweden and seven specimens from the Bohemian Basin. It is notable that most specimens have been found in areas situated close to ancient massifs. According to Naidin (1964) the species of Actinocamax from the Central
European Subprovince known to him ( $A$. strehlensis, $A$. bohemicus and $A$. paderbornensis) are different from those appearing in the Central Russian Subprovince. This point of view is supported by the present study. $A$. bohemicus and $A$. paderbornensis as understood in the present paper differ from' all other species of $A C$ tinocamax in the North European Province by the shape of the guard which is cylindrical to subcylindrical in ventral view and conical in lateral view. Moreover, $A$. paderbornensis differs from all other species of Actinocamax in the North European Province by the large size of the guard. A. strehlensis is poorly known, since only two specimens have been figured, both of which appear to be lost. This species shows some resemblance to $A$. intermedius, but differs in the structure of the anterior end of the guard and by having a smooth guard.

A. esseniensis n. sp. shows some resemblance to various species and subspecies from the Central Russian Subprovince such as $A$. coronatus, $A$. intermedius, $A$. medwedicicus from the Turonian and early Coniacian and Gonioteuthis westfalica mujnakensis from the late Coniacian. All these species and subspecies have guards which are lanceolate in ventral view and are more or less flattened ventrally. Moreover, they all have a more or less shallow pseudoalveolus, apart from $A$. intermedius. As pointed out above, some of these forms are distinguished on the basis of minor differences, and a study on further material of these forms may show that some of them should be placed in synonymy.

The relationship of $A$. bohemicus and $A$. paderbornensis to the Cenomanian species of $A c$ tinocamax is unknown at present, as is the relationship to the late Coniacian Belemnitella and Gonioteuthis lineages, respectively.

On the other hand, $A$. bohemicus and $A$. paderbornensis show resemblance in various characters (e.g. shape of guard, structure of anterior end and in the case of $A$. paderbornensis also size of guard) to some specimens of $A$. manitobensis as understood by Jeletzky $(1950,1961)$ from the Turonian of North America (see discussion above). However, the material of $A$. manitobensis on which Jeletzky $(1950,1961)$ based his revision was stratigraphically poorly located and probably spans more than one zone. Moreover, the diagnosis for $A$. manitobensis 
proposed by Jeletzky (1961) is not workable, because it is so broad that many species of $A c$ tinocamax could be classified as $A$. manitobensis. Therefore, A. manitobensis needs a revision based on stratigraphically well-documented material, and it seems unwise at present to identify the European species with North American representatives of $A$. manitobensis.

It is worthy of note that in North America belemnites are unknown in the Cenomanian and the first representatives are from the Turonian (Jeletzky 1950), an unusual situation in view of the restricted distribution of belemnites in the Turonian in the North European Province (see above).

The first member of the Gonioteuthis lineage, $G$. westfalica praewestfalica, and the first member of the Belemnitella lineage, $A$. l. lundgreni, are both characterized by having ventrally flattened guards which are lanceolate in ventral view, but A. l. lundgreni differs from $G$. westfalica praewestfalica notably by having a deeper pseudoalveolus and being larger. A. esseniensis $\mathrm{n}$. $\mathrm{sp}$. and the following representatives from the Central Russian Subprovince: $A$. coronatus, $A$. intermedius, $A$. medwedicicus, and G. westfalica mujnakensis are characterised by their large, more or less ventrally flattened guards. In addition they have a deeper pseudoalveolus, apart from $A$. intermedius, than the first member of the Gonioteuthis lineage. They are, therefore, more closely related to the Belemnitella lineage than the Gonioteuthis lineage, and the ancestor of the Belemnitella lineage should probably be sought among these forms.

Acknowledgments. I thank Mr. C. J. Wood, Dr. C. Frieg, Dr. H. Prescher, and Prof. Dr. Fr. Schmid for placing material in their care at my disposal. I also thank Dr. V. Z. Makhlin and Prof. Dr. D. P. Naidin for providing me with casts of various belemnites from Russia. S. L. Jacobsen and J. Ågård prepared the photographs, and C. Rasmussen made figs 1-3 and table 1.

Dr. F. Surlyk and Prof. Dr. T. Birkelund read the manuscript critically and made valuable comments.

\section{Dansk sammendrag}

Belemniterne fra øvre Turonien-nedre Coniacien fra den Centraleuropæiske palæobiogeografiske Subprovins er blevet revideret og følgende arter anses for at være gyldige: Actinocamax strehlensis (Fritsch \& Schlönbach), A. bohemicus Stolley, A. paderbormensis Schlüter $\operatorname{og} A$, esseniensis n. sp. I arbejdet diskuteres den taxonomiske vardi af forskellige karakterer hos belemniter, og det konkluderes, at formen af rostrum er en vigtigere karakter end tilstedeværelsen af granulation. De reviderede arter sammenlignes dels med samtidige arter fra den Centralrussiske Subprovins og den Nordamerikanske Provins, og dels med stratigrafisk ældre og yngre arter af Actinocamax fra den Nordeuropæiske Provins. Den palæobiogeografiske fordeling og evolutionære udvikling af belemniterne fra nedre del af $\emptyset$ vre Kridt diskuteres.

\section{References}

Amold, H. 1964a: Die Erforschung der westfälischen Kreide und zur Definition der Oberkreidestufen und -zonen. Forschr. Geol. Rheinld. Westf. 7, 1-14.

Arnold, H. 1964b: Die Verbreitung der Oberkreidestufen im Münsterland und besonders im Ruhrgebiet. Fortschr. Geol. Rheinld. Westf. 7, 679-690.

Barrois, C. 1876: Recherches sur le Terrain Crétacé Supérieur de l'Angleterre et de l'Irlande. Ann. Soc. Geol. Nord 3, 189-205.

Bergström, J., Christensen, W. K., Johansson, C. and Norling, E. 1973: An extension of Upper Cretaceous rocks to the Swedish west coast at Särdal, Bull. geol. Soc. Denm. 22, 83-154.

Birkelund, T. 1956: Upper Cretaceous belemnites from West Greenland. Meddr Grønl. 137(9), 28 pp.

Birkelund, T. 1973: A note on Pseudopuzosia sp. from Särdal. In: Bergström, J., Christensen, W. K., Johansson, C. \& Norling, E.: An extension of Upper Cretaceous rocks to the Swedish west coast at Särdal. Bull. geol. Soc. Denm. 22, 141-142.

Christensen, W. K. 1971: Belemnitella propinqua propingua (Moberg, 1885) from Scandinavia. Bull. geol. Soc. Denm. 20, 369-384.

Christensen, W. K. 1973: The belemnites and their stratigraphical significance. In: Bergström, J., Christensen, W. K., Johansson, C. \& Norling, E.: An extension of Upper Cretaceous rocks to the Swedish west coast at Särdal. Bull. geol. Soc. Denm. 22, 113-140.

Christensen, W. K. 1974: Morphometric analysis of Actinocamax plenus from England. Bull. geol. Soc. Denm. 23, $1-26$.

Christensen, W. K. 1975a: Upper Cretaceous belemnites from the Kristianstad area in Scania. Fossils and Strata 7, 69 pp.

Christensen, W. K. 1975b: Designation of lectotypes for Gonioteuthis westfalicagranulata and $G$. granulataquadrata. Paläont. Z. 49, 126-134.

Christensen, W. K. 1976: Palaeobiogeography of Late Cretaceous belemnites of Europe. Paläont. Z. 50, 113-129.

Christensen, W. K., Ernst, G., Schmid, F., Schulz, M.-G. and Wood, C. J. 1975: Belemnitella mucronata mucronata (Schlottheim, 1813) from the Upper Campanian: neotype, biometry, comparison and biostratigraphy. Geol. Jb. A28, 27-57.

Ernst, G. 1964: Ontogenie, Phylogenie und Stratigraphie der Belemnitengattung Gonioteuthis Bayle aus dem nordwestdeutschen Santon/Campan. Fortschr. Geol. Rheinld. Westf. 7, 113-174.

Ernst, G. and Schulz, M.-G. 1974: Stratigraphie und Fauna des Coniac and Santon im Schreibkreide-Richtprofil von Làgerdorf (Holstein). Mitt. geol.-Paläont. Inst. Hamb. 43, $5-60$.

Ernst, G., Schmid, F. and Klischies, G. 1979: Multistratigraphische Untersuchungen in der Oberkreide des Raumes Braunschweig-Hannover. Aspekte der Kreide Europas. IUGS Ser. A, 6, 11-46.

Frič, A. 1883: Studien im Gebiete der Böhmischen Kreideformation. III. Die Iserschichten. Arch. naturw. Landesdurchforsch. Böhmen 5(2), $140 \mathrm{pp}$. 
Fric, A. 1889: Studien im Gebiete der Böhmischen Kreideformation. IV. Die Teplitzer Schichten. Arch. naturw. Landesdurchforsch. Böhmen 7(2), $119 \mathrm{pp}$.

Fritsch, A. and Schlönbach, U. 1872: Cephalopoden der böhmischen Kreideformation. 52 pp. Prag.

Gale, A. S. and Woodroof, P. B. 1981: A Coniacian ammonite from the 'Top Rock' in the chalk of Kent. Geol. Mag. 118, 557-560.

Geinitz, H. B. 1872-1875: Das Elbthalgebirge in Sachsen. II. Der mittlere und obere Quader. Palaeontographica 20. II. Teil, $245 \mathrm{pp}$.

Grossouvre, A. de 1901-1903: Recherches sur la Craie Supérieur. Premiere Partie: Stratigraphie Générale. 1013 pp. Paris.

Hancock, J. M. and Kennedy, W. J. 1981: Upper Cretaceous ammonite stratigraphy: Some current problems. In: House, M. R. \& Senior, J. R. (Eds.): The Ammonoidea, Syst. Assoc. Spec. Vol. 18, 531-553. Acad. Press. London/ New York.

Hinte, J. E. van 1979: The Coniacian, Santonian and Campanian stratotypes. Lethaia $12,183-187$.

Jeletzky, J. A. 1948: Sowerby's and Sharpe's Belemnites lanceolatus and their relation to Belemnites lanceolatus Schlotheim, 1813. Geol. Mag. 85, 338-348.

Jeletzky, J. A. 1950: Actinocamax from the Upper Cretaceous of Manitoba. Bull. Geol. Surv. Can. 15, 27 pp.

Jeletzky, J. A. 1961: Actinocamax from the Upper Cretaceous Benton and Niobrara Formations of Kansas. J. Paleont. $36,501-531$.

Kauffman, E. G. 1977: Geological and biological overview: Western Interior Cretaceous Basin. The Mountain Geologist 14, 75-99.

Kauffman, E. G. 1978a: British Middle Cretaceous inoceramid biostratigraphy. Anns Mus. Hist. Nat. Nice 4, 12 pp.

Kauffman, E. G. 1978b: An outline of Middle Cretaceous marine history and inoceramid biostratigraphy in the Bohemian Basin, Czechoslovakia. Anns Mus. Hist. Nat. Nice 4, $12 \mathrm{pp}$.

Kauffman, E. G., Cobban, W. A. and Eicher, D. L. 1978: Albian through Lower Coniacian strata, biostratigraphy and principal events, Western Interior United States. Anns Mus. Hist. Nat. Nice 4, 52 pp.

Kennedy, W. J. and Hancock, J. M. 1978: The Mid-Cretaceous of the United Kingdom. Anns Mus. Hist. Nat. Nice 4, $72 \mathrm{pp}$.

Kongiel, R. 1962: On belemnites from Maastrichtian, Campanian and Santonian sediments in the Middle Vistula valley (Central Poland). Prace Muz. Ziemi 5, 148 pp.

Klein, V. and Soukup, J. 1966: The Bohemian Cretaceous Basin. In: Svoboda, J. (Ed.): Regional Geology of Czechoslovakia. Part 1: The Bohemian Massif, 487-512. Publishing House of the Czechoslovak Academy of Sciences. Prague.

Makhlin, V. Z. 1965: New Late Turonian Goniocamax of the Volga region. Paleont. Zh. 4, 26-32. [In Russian].

Naidin, D. P. 1964: The Upper Cretaceous belemnites of the Russian Platform and contiguous regions, Actinocamax, Gonioteuthis, Belemnellocamax. Moscow University Press, 190 pp. [In Russian].

Naidin, D. P. 1981: The Russian Platform and the Crimea. In: Reyment, R. A. \& Bengtson, P. (Eds.): Aspects of MidCretaceous Regional Geology, 29-68. Acad. Press. London.
Peake, N. B. and Hancock, J. M. 1970: The Upper Cretaceous of Norfolk. Revised edition. Trans. Norfolk Norwich nat. Soc. 293-339.

Prescher, H. 1981: Probleme der Korrelation des Cenomans und Turons in der Sächsischen und Böhmischen Kreide. $Z$. Geol. Wiss. 9, 367-373.

Rawson, P. F., Curry, D., Dilley, F. C., Hancock, J. M., Kennedy, W. J., Neale, J. W., Wood, C. J. and Worssam, B. C. 1978: A Correlation of Cretaceous rocks in the British Isles. Geol. Soc. Lond. Spec. Rep. 9, 70 pp.

Schlüter, C. 1874: Die Belemniten der Insel Bornholm. Z. dt. geol. Ges. 26, 827-855.

Schlüter, C. 1876: Cephalopoden der oberen deutschen Kreide. Teil 2. Palaeontographica 24, 123-263.

Schlüter, C. 1894: Über den ersten Belemniten im jüngsten Pläner mit Inoceramus cuvieri. Z. dt. geol. Ges. Jg. 1894, 281-288.

Schulz, M.-G. 1979: Morphotnetrisch-variationsstatistische Untersuchungen zur Phylogenie der Belemniten-Gattung Belemnella im Untermaastricht NW-Europas. Geol. $\mathrm{Jb}$. A47, 3-157.

Seibertz, E. 1979a: Probleme der Turon-Gliederung Nordeuropas (Oberkreide) im überregionalen Vergleich. Newsl. Stratigr. 7, 166-170.

Seibertz, E. 1979b: Biostratigraphie im Turon des SE-Münsterlandes und Anpassung an die internationale Gliederung aufgrund von Vergleich mit anderen OberkreideGebieten. Newsl. Stratigr. 8, 111-123.

Seitz, O. 1956: Über Ontogenie, Variabilität und Biostratigraphie einiger Inoceramen. Paläont. Z, 30, 3-6.

Seitz, O. 1959: Vergleichende Stratigraphie der Overkreide in Deutschland und in Nordamerika mit Hilfe der Inoceramen. 20th Int. Geol. Congr. Sympos. Cret., 113-130.

Sokolowski, S. (Ed.) 1976: Geology of Poland, Vol. 1 Stratigraphy, Part 2 Mesozoic. Publishing House Wydawnictwa Geologiczne. Warsaw. $859 \mathrm{pp}$.

Soukup, J. 1959: Die Kreide der Böhmischen Masse. Jb. Staatl. Mus. Min. Geol. 5, 85-89.

Stolley, E. 1916: Neue Beiträge zur Kenntnis der norddeutschen oberen Kreide, I-IV.Jber. niedersächs. geol. Ver. 9, 95-104.

Tröger, K.-A. 1981a: Zu Problemen der Biostratigraphie der Inoceramen und der Untergliederung des Cenomans und Turons in Mittel- und Osteuropa. Newsl. Stratigr. 9, 139-156.

Tröger, K.-A. 1981b; German Democratic Republic. In: Reyment, R. A. \& Bengtson, P. (Eds.): Aspects of Mid-Cretaceous Regional Geology, 1-28. Acad. Press, London.

Tröger, K.-A, and Wolf, L. 1960: Zur Stratigraphie und Petrographie der Strehlener Schichten. Geologie 9, 288-298.

Wiedmann, J, 1979: Die Ammoniten der NW-deutschen, Regensburger und Ostalpinen Overkreide im Vergleich mit den Oberkreidefaunen des westlichen Mediterrangebiets. Aspekte der Kreide Europas. IUGS, Ser. A, 6, 335-350.

Wright, C. W. 1979: The ammonites of the English Chalk Rock (Upper Turonian). Bull. Br. Mus. nat. Hist. (Geol.) 31, 281-332. 